TITLE: Identity crisis: A theoretical analysis of 'team identification' research RUNNING HEAD: Team identification

\author{
Daniel Lock* \\ Bournemouth University \\ Poole, UK \\ lockd@bournemouth.ac.uk \\ Bob Heere \\ University of South Carolina \\ Columbia, United States \\ bheere@hrsm.sc.edu
}

*Corresponding author

\begin{abstract}
Research question: Existing team identification research uses various definitions, conceptualisations, and theoretical frameworks. In this paper, we provide a theoretical analysis of previous research using the two dominant theoretical approaches: identity theory and the social identity approach. Our primary purpose is to provide a theoretical framework for the on-going study of 'team' identification in sport management research.

Findings: Scholars have used identity theory (role) and the social identity approach (group) in their quest to understand team identification, however, limited attention has been paid to the differences between the two frameworks. We focus on two aspects of role and group
\end{abstract}


identification that epitomize divergence in terms of analytical focus and explanations for behavior: the basis for identification and salience.

Implications. The manuscript concludes with three recommendations for future research. First, with the aim of making future research more specific, we recommend the use of fan (spectator) identification in studies using identity theory and team identification (organisation / brand) in studies exploring the influence of group identity. Second, we outline definitions for role (fan) and group (team) identification in sport research. Finally, we reflect on the measurement of team identification.

Keywords: Team identification, Fan identification, Identity theory, Social identity approach, Consumer behaviour. 
Identity crisis: A theoretical analysis of 'team identification' research

A strength of the sport management academy is its multidisciplinarity, diversity and flexibility. These characteristics provide a fertile arena in which scholars apply, or develop, theoretical perspectives in relation to an industry synonymous with high levels of consumer participation and involvement. Diverse perspectives can offer new ways of tackling problems; however, a potpourri of ideas and concepts can also create issues. In this paper, we concentrate on the genesis of 'team identification ${ }^{1}$ ' research; a stream of scholarship that, for a couple of reasons, exemplifies the pitfalls of theoretical and conceptual diversity. First, it demonstrates how the meaning of a construct can be confused when published work uses multiple definitions to conceptualise a construct. Second, it exemplifies the lack of focus that can ensue when theories are used without critical analysis of their differences or suitability to a specific research problem.

Knowledge and understanding of team identification was driven by the pioneering work of sport psychologists and marketing scholars in the 1990s and new millennium (e.g., Fink, Trail, \& Anderson, 2002; Sutton, McDonald, Milne, \& Cimperman, 1997; Wann \& Branscombe, 1990, 1993). Initially, scholars focused their attention on understanding consumer behaviour and measuring team identification (e.g., Wann \& Branscombe, 1990, 1993). The initial enthusiasm for understanding fan behaviour was not coupled with strong theoretical foundations (Wann, Melnick, Russell, \& Pease, 2001). Research on team identification, therefore, started with vague theoretical underpinnings, which has led to the definition and application of the construct following a somewhat haphazard path; an observation as relevant today as it was in the early 1990s.

Obfuscating matters further, as the field has developed, scholars have used theoretical frameworks from sociology $\mathrm{y}^{2}$ and social psychology to explore team identification (Jacobson, 2003; Trail, Anderson, \& Lee, in press; Trail \& James, 2016). The majority of existing 
research uses social identity theory (Tajfel \& Turner, 1979), while a smaller group of researchers have used identity theory (Stryker, 1968) to frame their analysis. If the two theories were equivalent this would not present an issue. Fundamentally, however, identity theory and social identity theory concentrate on different levels of analysis (Hogg, Terry, \& White, 1995; Stets \& Burke, 2000). Identity theorists focus on the interactions between people that shape role behaviour. Social identity theorists, on the other hand, explore how group membership leads to individuals sharing common characteristics and values which provide a basis for normative behaviour.

In light of these differences, the perspective we adopt mirrors that of Brewer (2001), Jacobson (2003), Deaux and Martin (2003), Ashmore, Deaux and McLaughlin-Volpe (2004), Thoits and Virshup (1997), and Stets and Burke (2000), all of whom argue that the social roles a person occupies (e.g., a team fan) and the groups to which she belongs (e.g., a sport team) influence behaviour. In this sense, the two theoretical approaches provide a more holistic framework to understand the social behaviour of sport consumers. For this reason, we aim to contribute to the extant literature on team identification by exploring the assumptions underlying identity theory and the social identity approach in order to provide some clarity for on-going research. Commensurately, our purpose is to develop a framework that sets an agenda for understanding how role and group identification affect sport consumer behaviour.

\section{Identity crisis}

In this section, we have two primary objectives. First, to demonstrate that researchers define and conceptualise team identification multifariously. Second, to introduce identity theory and the social identity approach as the lenses for our critical analysis of team identification research. 


\section{Background to team identification research}

Gantz (1981) provided one of the first empirical links between team identification and consumption, observing that identification with a player or team correlated with television viewership. Team identification research began in earnest when Daniel Wann and his colleagues started a systematic programme of investigation in 1990 (e.g., Branscombe \& Wann, 1992; Wann \& Branscombe, 1990, 1993). They focused on: spectators tendency to associate with successful teams and disassociate from unsuccessful ones (Wann \& Branscombe, 1990); construct measurement (Wann \& Branscombe, 1993); and the formation and continuation of identification (Wann, Tucker, \& Schrader, 1996). This work has made a vast contribution to understanding of sport consumers; however, its applied focus came at the expense of theoretical detail (Wann et al., 2001). Perhaps because of the vague theoretical basis, scholars have defined and conceptualised the construct in a range of ways. Figure 1 displays previous definitions of team identification to illustrate this point.

---- Insert Figure 1 about here ----

The definitions shown in Figure 1 exhibit an array of language, terms and concepts. However, there are four areas of consistency that shed light on what 'team identification' has meant in research to date. First, with the exception of Sutton et al. (1997), the definitions refer to a consumer's perception (Ashforth \& Mael, 1989; Elsbach, 1999; Fink et al., 2002; Foster \& Hyatt, 2007; Smith, Graetz, \& Westerbeek, 2008), orientation (Trail, Anderson, \& Fink, 2000), knowledge (Tajfel, 1982; Underwood, Bond, \& Baer, 2001), cognitive state (Pritchard, Stinson, \& Patton, 2010), or psychological connection to a team (Branscombe \& Wann, 1992; Wann, Fahl, Erdmann, \& Littleton, 1999). Each of these terms implies that a consumer cognitively realises that he is connected to a person, group or team to some extent.

Second, eight of the definitions refer to identification interacting with a person's selfconcept. References include: orientation of self (Trail et al., 2000), representation or 
extension of self (Branscombe \& Wann, 1992; Wann et al., 1999), part of an individual's self-concept (Tajfel, 1982), or an active connection between the identity of a person [self] and an organisation (Elsbach, 1999; Foster \& Hyatt, 2007). There is some consensus, therefore, that team identification interacts with - or extends - a person's self-concept.

Third, Branscombe and Wann (1992), Gwinner and Swanson (2003), Smith et al. (2008), and Wann et al. (2011) all refer to identified consumers having a vested interest in team performances. This implies that identified (non-identified) consumers care (do not care) about the performances of their team in comparison to others. Vested interests also usurp onfield performances. Discussing this point, Heere (2016) argues that consumers 'evaluate the community itself', while Elsbach (1999) notes a 'positive relational categorization' between self and organisation. There is some consensus, therefore, that consumers evaluate the status of their team or group in terms of team performance or status (Heere \& James, 2007b).

Fourth, five of the definitions mention that team identification has some degree of emotional importance. Trail et al. (2000) mentions close attachment, Sutton et al. (1997) emotional involvement, while Heere (2016) and Tajfel (1982) describe the emotional value and significance of identification. These examples intimate that for some consumers, team identification is peripheral, while for others it is an emotionally important part of everyday life. In summary, the prevailing literature reaches some consensus that team identification involves: (a) cognition, (b) interaction with a consumer's self-concept, (c) interest in, and evaluations of group status, and (d) some degree of emotional value.

The commonalities in definitions are accompanied by significant differences. Prior definitions, apart from Trail et al. $(2000)^{3}$, fall into two main categories: consumer to team, and consumer with group. Adherents to the first category adopt a mainly psychological conceptualisation of identification in which the relationship exists between an individual and a team (Branscombe \& Wann, 1992; Gwinner \& Swanson, 2003; Mahony, 1995; Sutton et 
al., 1997; Wann et al., 1999). Branscombe and Wann's (1992, p. 1017) definition references someone that is a 'fan of the team, involved with the team, concerned with the team's performance, and view the team as a representation of themselves' (Later updated to “psychological connection to a team...."; Wann et al., 1999; Wann, Waddill, Polk, \& Weaver, 2011). Gwinner and Swanson (2003), Smith et al. (2008), and Sutton et al. (1997) adopt similarly psychological perspectives. Perhaps as a consequence of this stream of research, some scholars have described team identification as an attitude (e.g., Yoshida, Heere, \& Gordon, 2015). That is, identification is a psychological construct related to the favour or disfavour a person feels for a perceptual object (e.g., Eagly \& Chaiken, 1993). In this first category of research, behaviour is a by-product of a relationship between consumer and team.

The second category: consumer with group, conceptualises team identification as an identity shared by individuals that work for, or support, an organisation (Ashforth \& Mael, 1989; Elsbach, 1999; Foster \& Hyatt, 2007; Underwood et al., 2001). The most frequently used definitions in this category stem from social identity theory (Tajfel, 1982) and research on organisational identity (Ashforth \& Mael, 1989). Researchers have used Tajfel's (1982) definition of group identification, which includes a person's '.... knowledge of their membership of a social group'. Other scholars have used Ashforth and Mael's (1989) classic description of organisational identification as 'the perception of oneness... to some human aggregate'. In contrast to the first category, these definitions refer to a person belonging to a group or social aggregate containing other people, be they players, staff, or consumers. Thus, in this social psychological iteration of team identification research, shared group membership creates a consensual framework for behaviour. 


\section{Theoretical frameworks}

On the surface, the issues created by advancing research with two broad conceptualisations might seem negligible; however, the differences flow quite logically from two characteristics of existing research that we have already discussed. (1) Early work developed without a strong theoretical background (e.g., Branscombe \& Wann, 1992; Wann \& Branscombe, 1990), and (2) more recent work uses two different theoretical approaches to inform studies of team identification.

Most theoretically driven work uses social identity theory, while a smaller body of work draws on identity theory. Fundamentally, identity theory and the social identity approach focus on different levels of analysis (e.g., Brewer, 2001; Hogg et al., 1995; Stets \& Burke, 2000; Thoits \& Virshup, 1997). Identity theorists typically explore how the roles and counter-roles people occupy in social situations influence behaviour (Stets \& Burke, 2000). In contrast, social identity proponents study how belonging to a social group or category (e.g., a sport team) provides a basis for similarity and cohesive behaviour (Tajfel \& Turner, 1979; Turner, Hogg, Oakes, Reicher, \& Wetherell, 1987). The theoretical, conceptual, and terminological differences inherent to each approach have been discussed in detail by Hogg et al. (1995) and Stets and Burke (2000). Sport researchers, with the exception of Jacobson (2003), Trail et al. (in press), and Trail and James (2016), have tended to construct studies using either identity theory or social identity theory without attention to the issues this creates.

\section{Theoretical framework}

Our intention is not to premise either theoretical approach. Like Brewer (2001), Ashmore et al. (2004), Deaux and Martin (2003), Thoits and Virshup (1997), and Stets and Burke (2000) we view each framework as well suited to certain problems. There are also some areas of theoretical common ground (Stets \& Burke, 2000). For example, adherents to 
both approaches argue that social structures and contexts shift behaviour from enactments of personal identity to actions shaped by roles or groups (Stryker, 1968; Turner \& Brown, 1978). (In this paper, we eschew a continued discussion of personal identity in favour of a detailed discussion of the social effects of role-based interactions and group membership on consumer identities.) In the following section, we structure our discussion from the individual and work outwards to review role-based identities and then identification with groups. To achieve this aim we explore the theoretical basis of relational role-based identities before reviewing the major tenets of social identity research. Both perspectives have a rich intellectual history, which prohibits an expansive review. Instead, we focus on two main points that illustrate clear differences between the two theoretical approaches: (a) the basis of identification with roles and groups; and (b) role and group salience. This analysis enables us to illustrate the conceptual differences and limitations of each approach.

\section{Identity theory}

Burke and Stets (1999, p. 349) define role identification as 'a set of meanings applied to the self in a social role or situation, defining what it means to be who one is in that role or situation'. Brewer (2001) argues that role identities represent the relational and interpersonal parts of an individual's self-concept (see also Jacobson, 2003). Thus, while conceptually distinct from group identification, Brewer argues that identity theory offers important insights into the interpersonal interactions that shape intragroup behviour. Originally developed by Stryker (1968), identity theory has informed investigations of (role) team identification and points of attachment (e.g., Kwon, Trail, \& Anderson, 2005; Laverie \& Arnett, 2000; Shapiro, Ridinger, \& Trail, 2013; Trail, Anderson, \& Fink, 2005). Trail et al. (2005) found a positive relationship between team identification and self-esteem. Shapiro et al. (2013) found that role identification (or points of attachment) had a positive and significant mediating influence on behavioural intentions to watch sport. In a study of ticket purchasing behaviours, Dwyer et al. 
(2013) found that identified consumers displayed higher levels of knowledge in relation to advanced ticket buying processes. Each of these studies used a cross-sectional research design and measured role identification using the Team Identification Index (TII) or Points of Attachment Index (PAI). By concentrating on consumer identification, or different points of attachment, the authors of these studies did not explore how social interactions and social structures influence behaviour.

The symbolic interactionist perspective from which identity theory emerged (Mead, 1934 ) is rooted in the notion that role behaviour is premised on the negotiation of multiple selves (McCall \& Simmons, 1978; Stryker, 1968). Rather than a generic performance of consumer identities, identity theorists explore how the counter-roles performed by other individuals in a situation lead to the enactment of specific behaviours. In this sense, identity theory is premised on social structures and social interactions providing a social and contextual framework for behaviour (Burke \& Reitzes, 1981; Stryker, 1968; Stryker \& Serpe, 1982); a point that is mainly absent in sport consumer research. Jacobson (2003) provides a pertinent exception in her research on the creation of a professional team fan. She argues that the relational ties individuals share with family and friends are crucial in the formation of team identification. While making a strong theoretical contribution, Jacobson focussed on the operational uses of identity theory in explaining the creation of the 'sport fan' without providing a detailed contrast to differentiate it from the social identity approach. As such, we discuss identity theory in relation to two distinguishing features: role identification and salience.

Role identification. Previous sport research probes populations that already consume teams (e.g., Kwon et al., 2005; Laverie \& Arnett, 2000; Shapiro et al., 2013; Trail et al., 2005). Therefore, it does not explore how social structures (e.g., schools or communities) influence the likelihood that a person will identify with certain social roles (Kleine \& Kleine, 
2000; McCall \& Simmons, 1978; Stryker \& Serpe, 1982). Reflecting the structuralist inclinations of its authors, relational networks (e.g., family or friendship groups), demographics (e.g., age, gender or social class) and organisations (e.g., crèches, schools or workplaces) increase (decrease) the chances of a person being socialised into a role (Stets \& Burke, 2014). Belonging to a specific social class (e.g., blue collar worker), for example, can increase (decrease) the likelihood that an individual will play polo or golf. Yet, this central proposition from identity theory (and sociology broadly) gains little traction in the team identification literature. As this proposition implies that the market share of sport organisations is limited by existing patterns of social structure, it seems a crucial omission.

The social structures in which a person interacts makes some identities more probable than others (Kleine \& Kleine, 2000). However, a person needs to accept that a role label applies to her (i.e., it is voluntary) for it to influence decision making (e.g., I am a sport fan). Stryker (2008, p. 20) explains that as these 'self-cognitions' form, role schemas develop that provide a blueprint for role-appropriate behaviour. The appropriateness of role-behaviour is verified by the consumer and the other role actors in a social context in relation to an identity standard (Burke \& Stets, 1999). For example, how a mother, or fan, or sister performs her roles in relation to a father, or fan, or brother. The performance of these roles (re)produces a person's links to the social structures that give them meaning in daily life (Burke \& Reitzes, 1981); for example, mother to family, sport fan to team, and runner to running club. It is these ties that provide a social context for social interactions - which from a symbolic interactionist perspective - acts as the frame of reference for the development of self and consumer behaviour (Stets \& Burke, 2003).

Role 'salience'. The concept of role salience is central to the theoretical propositions advanced in identity theory. Sport-based research, with the exceptions of Laverie and Arnett (2000) and Arnett et al. (2003), concentrates on the strength or importance of identification 
(Dwyer et al., 2013; Shapiro et al., 2013; Trail et al., 2005, in press). Laverie and Arnett (2000) studied U.S. collegiate sport fans to test factors influencing identity salience. They found that situation involvement, enduring involvement, and attachment correlated with identity salience and, in turn, identity salience had a positive influence on attendance at university women's basketball team matches. Arnett et al. (2003) conducted a study of relationship marketing efforts to engage with university alumni. They found that identity salience correlated with donations to the athletic programme and promotion of the university to others. In both of these studies Laverie and Arnett (2000) and Arnett et al. (2003) used different iterations of Callero's (1985) blood-donor salience scale to measure identification with one role (see discussion of the salience hierarchy, below). Laverie and Arnett (2000), Arnett et al. (2003), Dwyer et al. (2013), Shapiro et al. (2013), Trail et al. (2005), and Trail et al. (in press) measure identification with a single role (e.g., being a fan is important to me). In fact, Trail et al. (in press) argue that the importance of a role to a person is the essence of identity theory. We deviate from this perspective as it excludes the influence of social structures and other role actors from explanations of behaviour, both of which are central features of identity theory (Stets \& Burke, 2014; Stryker, 2008). There are two concepts that buttress this approach to role identity: a salience hierarchy and [social] commitment. To emphasise the conceptual relevance of these two facets of role salience, we discuss each in the following sections.

Salience hierarchy. Callero (1985, p. 203) clearly explicated the conceptual idea of a salience hierarchy in the following passage:

Critical to this perspective is the assumption that some role-identities are more a part of the self than others and consequently have a variable effect on the self-concept. Thus, for one person the occupational role-identity may be the dominant aspect of the 
self, taking precedence over other role-identities and affecting general selfperceptions and actions [emphasis added].

He illustrates that the different roles a person occupies are of variable importance. Therefore, the importance of one role is related to the other social positions that an individual occupies. An individual might find being a fan important, but if it is less important to him than being an academic and demands for the two roles compete, he is less likely to behave as a fan, and more likely to perform as an academic. The salience hierarchy, therefore, provides a contextualised method to identify the most influential roles in a person's life (Stryker \& Serpe, 1994). Points of attachment research draws on the strand of identity theory; however, it does so without taking a broad view of the roles (e.g., mother, parent etc.) with which a consumer might identify beyond the team (e.g., players) or community (Kwon et al., 2005; Robinson \& Trail, 2005; Trail, Robinson, Dick, \& Gillentine, 2003). Therefore, these studies do not explore the fundamentally relational notion of a salience hierarchy as defined elsewhere (Curry \& Weaner, 1987; Stryker \& Serpe, 1982). This presents an opportunity for researchers to explore how the relative salience of different social positions influences consumer behaviour (e.g., gender, family status, social class etc.) (see Stryker, 2008 for a rationale on the necessity for including these variables in role-based analyses).

Social commitment. Stryker (1968), posits that the placement of a role in a person's salience hierarchy is determined - to a large extent - by the social structures and networks in which he interacts (Burke \& Stets, 1999; Stryker \& Serpe, 1982). A person's ties to those with whom he interacts in a social structure are described as commitment in identity theory (Burke \& Stets, 1999; Stryker \& Serpe, 1982). To avoid confusion with psychological commitment (e.g., Mahony, Madrigal, \& Howard, 2000), we refer to this process as social commitment for the remainder of this paper. Stryker and Serpe (1994, p. 19) define social commitment as 'the social and personal costs entailed in no longer fulfilling a role based on a 
given identity'. In other words, a person will continue to perform some social roles because ceasing would lead to some sense of personal and social loss. For example, on moving to university, an individual might forgo the opportunity to attend matches with his parents and siblings in favour of forming a new role identity as a student. Although adopting a new role, the inability to consume matches with his family and siblings might still equate to a sense of social loss. The extent of loss will relate to the position of the role in his salience hierarchy. The extent of a person's social commitment to a role is operationalised in identity theory quantitatively and qualitatively (Serpe, 1987; Stryker \& Serpe, 1982, 1994). The quantitative metric captures the number of people that tie a person to a role. As not all interpersonal relationships are equally meaningful, the qualitative component measures the importance of ties to other individuals in a social structure (e.g., consumer - to - consumer; Uhrich, 2014). It follows, then, that roles tying a consumer to more people (quantitative) in a meaningful way (qualitative) will tend to occupy a more prominent position in her salience hierarchy (Stryker \& Serpe, 1982).

Like research on salience, social commitment has existed beyond the scope of most prior work on sport consumers. Katz and Heere $(2013,2015)$ hinted at the concept when they observed that tailgaters with weak team identities attended games due to shared social ties with other consumers (formed through other roles; e.g., work). Yet while concentrating on importance and strength (Arnett et al., 2003; Dwyer et al., 2013; Laverie \& Arnett, 2000; Shapiro et al., 2013; Trail et al., 2005), researchers have ignored the theoretical process argued to increase the salience of roles in a person's hierarchy (Stets \& Burke, 2014; Stryker $\&$ Serpe, 1994). If we want to use the theoretical crux of identity theory to offer guidance for practitioners, the relationship between social commitment and role salience is a crucial area for conceptual development. 
To illustrate the pervasive role of the salience hierarchy and social commitment in a consumer's behaviour, consider the following example. Imagine two fathers that have an equivalently strong team identification (as rated on a scale) and support the same team. Father one is more devoted to the social structure of his family than he is to the team. Thus, his social commitment to parenthood renders his role as father the dominant guide for behaviour in his salience hierarchy. Father two works and socialises with other fans on a daily basis and spends little time with his wife and children. For illustrative purposes, Father two's fan role is more salient than his parental one. In this example, both fathers might exhibit completely different attendance behaviours due to the relative importance of their parental and consumption roles. Father one may choose to spend the weekend with his children at home, whilst father two may leave his family to attend a match. To date, research from an identity theory standpoint ignores how these dynamics influence consumer behaviour.

\section{Social identity approach}

The social identity approach denotes the unison of social identity theory (Tajfel \& Turner, 1979) and self-categorization theory (Turner et al., 1987). Sport consumer research primarily draws on the first prong of the social identity approach: social identity theory. Relative to the literature using identity theory, this body of work is larger (see Rees, Haslam, Coffee, \& Lavallee, 2015 for an expansive review). Extant research concentrates on factors leading to team identification (Fink et al., 2002; Fisher \& Wakefield, 1998; Lock, Taylor, \& Darcy, 2011; Theodorakis, Wann, \& Weaver, 2012), the dimensional structure of the construct (Dimmock, Grove, \& Eklund, 2005; Heere et al., 2011; Heere \& James, 2007a; Lock, Funk, Doyle, \& McDonald, 2014), behavioural manifestations of identity strength (Boyle \& Magnusson, 2007; Gwinner \& Swanson, 2003; Lock, Taylor, Funk, \& Darcy, 2012; Madrigal, 2000; Theodorakis, Dimmock, Wann, \& Barlas, 2010; Wann \& Branscombe, 
1990), organisational responses to identity threats (Fink, Parker, Brett, \& Higgins, 2009), and image maintenance (Bernache-Assollant, Chantal, Bouchet, \& Lacassagne, 2016; BernacheAssollant, Laurin, \& Bodet, 2012; Delia, 2015; Doyle, Lock, Filo, Funk, \& McDonald, in press; Wann \& Branscombe, 1990). Like the research framed by identity theory, social identity adherents equate the strength of team identification with a range of positive teambased consumption behaviours.

The existing social identity-based research on team identification evinces the consumer - team and consumer with group approaches discussed. These differing conceptualisations occur in relation to a meta-theory that focuses on the way in which groups - as social structures - bias member attitudes and behaviours in favour of an in-group. As such, the social identity approach derives from a strongly social constructionist position (Abrams \& Hogg, 2004). Concomitant to this approach is a focus on the individual as shaped by the shared characteristics of a group. For this reason, the following discussion concentrates on the consumer with group conceptualisation of team identification. The social identity research into team identification also suffers from some basic limitations. In the following section we articulate the basis for identification with a group and then discuss how social identity information becomes salient in a consumer's operational self-concept.

Group identification. Social identity theorising is based on a couple of assumptions. First, people derive some part of their self-concept from the groups to which they belong (Bodet \& Bernache-Assollant, 2011; Tajfel \& Turner, 1979). Therefore, the groups that a person chooses to join have ramifications for his self-esteem (Abrams \& Hogg, 1988). Second, as a result of point one, a person will join groups that he perceives to reflect positively on his self-concept (Tajfel, 1969). Thus, while identity theorists provide a rigorous discussion of the relationship between social structures and role occupation; social identity proponents treat group identification as an aspirational process. That is, a person will join 
groups (where possible) that he perceives to be consonant with (Tajfel, 1969), or an extension of, his self-definition (Tajfel \& Turner, 1979).

These assumptions led Tajfel $(1982$, p. 2) to state two necessary components of group identification 'a cognitive one, in the sense of awareness of membership; and an evaluative one, in the sense that this awareness is related to some value connotations [emphasis added].' As in identity theory, social identity theorists assume a cognitive component to identification (Tajfel, 1982; Turner et al., 1987). Somewhat contrasting identity theory, however, this cognition relates to a person realising that she belongs to a group, where a 'group' is defined 'as two or more individuals who share a common social identification of themselves or... perceive themselves to be members of the same social category' (Turner, 1982, p. 15). Turner (1987) termed the process that made shared identification possible: selfcategorization. Specifically, once a person categorises their self as an interchangeable member of a group (e.g., Bayern Munich), it provides a basis for shared group identity.

The evaluative component refers to the value judgements a person makes about the degree group membership reflects positively or negatively on his self-concept (Tajfel, 1982). As our review of definitions reveals, this is a common theme in previous team identification research (See Figure 1). In social identity theory, Tajfel and Turner (1979) focused, primarily, on evaluations of intergroup status. In sport this concerns the extent that consumers of one team or athlete perceive their own group to be objectively (e.g., match results), or subjectively (e.g., our kit is nicer than your kit) superior to an out-group[s] (Lalonde, 1992). However, as social identity researchers have diversified attention to organisational contexts and smaller groups, they have started to acknowledge that out-groups are not omnipresent features of group life (Prentice, Miller, \& Lightdale, 1994). In small groups, bonds between group members can also form an identity that members evaluate positively (Lock \& Funk, 2016). Thus the baseline for identification to influence behaviour - from a social identity 
perspective - is an individual cognitively realising that he belongs to a social group that is evaluated based on its value to an individual or in terms of its intergroup status (e.g., Heere \& James, 2007b).

Cognition of shared identity provides the basis for exposure to in-group norms. These shared understandings of groups provide the basis for members to act according to consensual practices that define a team in relation to other organisations and groups (Foster \& Hyatt, 2008; Tajfel \& Turner, 1979). As norms become consensual, they create a framework for behaviours and attitudes that are simplified and biased in favour of in-group interests (Hogg \& Smith, 2007). The salient norms and values confer understanding of 'what we are', 'how we are distinctive', and 'how we behave' (Hogg \& Smith, 2007). Reed (2002) suggests that these normative understandings of group life confer specific modes of consumption onto individuals that offer in-group distinctiveness in relation to other teams, groups or organisations (see also Holt, 1995; Underwood et al., 2001). Little attention is paid in the sport-based literature to the way in which group norms become salient in a person's cognitive structure.

Group 'salience'. The extant literature demonstrates that consumers exhibit varying degrees of team identification (Funk \& James, 2001; Wann \& Branscombe, 1990). Mirroring work framed by identity theory, there has been a prolonged emphasis on the strength of team identification and its correlates (e.g., Boyle \& Magnusson, 2007; Wann \& Branscombe, 1993). There are, however, some notable applications of the social identity approach to salience in sport consumer research. Luellen and Wann (2010) found that rendering an outgroup salient in a social context enhanced the strength of team identification. Although implicit, Fink et al. (2009), and Reysen, Snider, and Branscombe (2012) rendered team identities salient in experimental designs. Fink et al. provided consumers with negative information about the off-field behaviour of a team and its players. The strong leadership 
response manipulation mitigated against reductions in team identification in their post-test. Reysen et al. manipulated a context in which fans were told the Kentucky Basketball stadium was going to be renamed following a philanthropic donation. Participants in the name change condition felt anger due to a perceived threat to team distinctiveness. Lastly, Delia (2015) conducted an interpretive study of team and university identification during fan expressions of team success in which she demonstrates how different group identities become salient simultaneously as fans consume matches.

There is extensive literature informed by the social identity approach in social psychology (Oakes, Turner, \& Haslam, 1991; Turner et al., 1987), and consumer research (Forehand, Deshpandé, \& Reed, 2002; Reed, 2002, 2004) that explores the salience of group identities. As demonstrated, this work has featured in sport consumer research fleetingly, or implicitly. Associated with this gap in prior work, we retain a limited understanding of the situational characteristics that lead to team identification becoming an active frame of reference for consumer behaviour (see Forehand et al., 2002; Oakes et al., 1991; Reed, 2002, 2004). This blunts our use of the social identity approach as an explanatory tool to offer recommendations for marketers that move beyond arguments for strengthening team identification (cf. Reed, 2002). Forehand et al. (2002) articulate three concepts that lead to group identities become salient in a person's self-concept: stable traits, stimulus cues, and social context. To address the limitations in previous work, we review each in the following sections.

Function of stable-traits. At an individual level quantitative evidence suggests that team identification is a relatively stable construct over time (Katz \& Heere, 2016; Lock et al., 2014; Wann \& Schrader, 1996). The strength of identification, or self-importance as it is termed in consumer research, refers to the enduring placement of an identity in a person's self-concept (Forehand et al., 2002; Lock \& Funk, 2016; Reed, 2002, 2004). We use the term 
self-importance (cf. Madrigal, 2000; Reed, 2002) as an umbrella term for centrality (Lock et al., 2012), emotional value (Tajfel, 1982), and interconnection (Heere \& James, 2007b), which all describe the meaning associated with a group identity. Forehand et al. (2002) describe the self-importance of a group identity as a stable trait in the sense that it persists over time. Self-important team identities are more accessible and prominent in memory (Oakes et al., 1991), which leads individuals to apply them as a frame of reference to make sense of a broader range of situations in everyday life.

Stimulus cues. Although self-importance elevates the accessibility of group norms in memory, the contextual environment offers stimuli that activate identities. For example, regardless of how important team identification is to a person, he is unlikely to use the norms and values of his team to make sense of which vegetables to select in the supermarket. In this sense, social identity theorists posit that salience occurs in social contexts that are relevant or which normatively fit the content of an identity (Oakes et al., 1991; Turner, Oakes, Haslam, \& McGarty, 1994). Specifically, a group identity will become a relevant frame of reference when group norms simplify the social context. Take, for example, a Texas Longhorn's fan heading to a store to purchase a key ring. It is unlikely that her team identification would inform the choice of key ring under normal circumstances (i.e., unbranded key rings). However, in the store she visits, there are key rings adorned with Oklahoma Sooners, Baylor Bears, and Texas A \& M branding. The normative rivalry the Longhorn's share with these teams would activate the team identity and preclude purchase of a key ring displaying rival branding. Forehand et al. (2002, p. 1087) describe this type of identity activation as the ‘function of stimulus cues'. Out-group symbols and members, in-group symbols and members, and words and images related to either of the former are sufficient stimulus cues to activate a group identity. While concentrating intently on the strength of identification, researchers have broadly ignored how practitioners can manipulate social environments with 
stimulus cues to activate team identities and, as a consequence, influence consumer behaviour.

Social context. Activation can also stem from identification with small groups or entities that are strongly differentiated from the mainstream (Goldman, Chadwick, Funk, \& Wocke, 2016). In this example, group identities become salient because they offer distinctiveness in relation to other actors or groups in a social context (Forehand et al., 2002). This aligns with Andrijiw and Hyatt's (2009) study of nonlocal Hartford Whalers fans. Instead of forming an identity with an established club in their local area, Andrijiw and Hyatt found that participants selected a nonlocal team to satisfy distinctiveness motives (cf. Brewer, 1991; Dimmock, 2009). More specifically, in social contexts that an individual perceives his need for belonging to be satiated through existing group memberships, he will seek out identity projects that make him distinctive in relation to others. Through this action, a consumer can gain distinctiveness by holding a category membership that is different to the other individuals in a social context, yet, sufficient to provide a positive contribution to his self-concept (Brewer, 1991; Dimmock, 2009).

\section{The tensions between roles and groups}

To this point, we have discussed role and group identification in terms of distinguishing characteristics. However, there is a danger that in doing so, we imply that they are separate processes that operate without overlap or crossover in the self-concept. Brewer $(1991 ; 2001)$ refutes this position explicating how competing motives for individual distinctiveness and group belonging bridge approaches that are exclusively role or group focussed. The relational interactions that predominate identity theorising can, and in many instances, do, occur in groups. As such, the individuals engaging in symbolic interactions are, in many cases, sharing and cultivating group-based understandings of ideal behaviour. Vice versa, the social identity approach is poorly equipped to explain intragroup behaviour as a 
product of interpersonal relations (Hornsey \& Jetten, 2004; Worchel, Iuzzini, Coutant, \& Ivaldi, 2000). This is despite the reality that many intergroup situations are founded on interpersonal interactions between group members. Moreover, it ignores that group norms are brought to life and learned through relational identities (Lock \& Funk, 2016; Sluss \& Ashforth, 2008). Thus, before considering how our framework might help to organise future consumer research using the theories discussed, we emphasise that the processes are interrelated in terms of behavioural influence. Furthermore, while we focus on future uses of identity theory and the social identity approach, it seems necessary to state that these approaches are poorly equipped to frame the competing needs for distinctiveness and belonging that sit between and around role and group identification. There is a nascent body of research on this subject in sport (Andrijiw and Hyatt, 2009; Goldman et al., 2016) that, in addition to our purpose here, provides a framework to explore the complex relations between individual, role, and group identities in the future.

\section{Applying the framework}

Our review reveals that team identification research has contributed greatly to understanding of sport consumers. However, it also demonstrates that scholars have applied a plethora of definitions, theories, and conceptual approaches to the topic. In addition, there are gaps in our understanding of how symbolic interactions and group identification shape consumer action. Therefore, we argue, there is a pertinent opportunity to advance understanding of team identification by underpinning future research with the distinctions we have advanced as a basis to explore each approach to consumer identities in more detail.

Table 1 summarises the major conceptual and theoretical differences that we have discussed.

$$
\text { --- Insert Table } 1 \text { about here --- }
$$

The differences displayed in Table 1 are significant, a point acknowledged in social psychology (Hogg et al., 1995; Stets \& Burke, 2000) and mostly ignored in sport consumer 
research (see discussions in Jacobson, 2003; Trail et al., in press; Trail \& James, 2016). In the following sections, we outline three implications of our review. First, we argue that the terms fan (role) and team (group) identification can be separated and used to explore different problems. Second, we outline theoretically based definitions of fan (role) and team (group) identification in order to catalyse more specific uses of these constructs in future studies. Third, we reflect on team identification measurement prior to offering some recommendations for future practice.

\section{Focus of identification}

Existing identity research uses fan, spectator, team, and organisation interchangeably. In this section, we consider the use of these terms with more specificity than the haphazard application that has unfolded to date.

Fan (spectator) identification (identity). Swanson and Kent (2015) lamented the confusing use of nouns in previous identification research. They used a social identity approach to advance recommendations for more logical uses of terms to precede identification. 'Fan identification', they argue, is a limited term that should be replaced with 'fan group identification' to imply a shared identity between consumers. Considering the arguments we have presented, this approach is limited as it only considers group-based identities. Heere (2016) offers an alternate perspective: he argues that team (organisation) descriptors refer to group identities; thus, supporting Swanson and Kent. However, he recommends the utility of using fan (spectator) identification to describe the role of being a consumer. Our theoretical framework tends to support the use of singular nouns, such as fan (spectator) identification, in studies that employ identity theory. It provides sport scholars with a descriptor that is theoretically appropriate, and specific at the level of a role actor (i.e., sport consumer). It follows that future studies of fan (spectator) identification can probe novel 
aspects of consumer behaviour, such as the role of social commitment, identity salience (as a ranked order of roles), and the influence of other consumers on behaviour. This also suggests a possible consumer identity angle to build upon recent studies of consumer-to-consumer interactions (cf. Uhrich, 2014). As we have shown, this terrain is relatively untouched and provides rich, sociologically-based opportunities for research development.

Team identification (identity). Mirroring the application of Swanson and Kent (2015), it seems logical for social identity driven studies to use collective nouns (e.g., team, organisation, or community identification) to reflect the group-based focus of the theory. From a social identity perspective, consumers share a common category membership with a group that - to varying extents - might consist of players, coaches, staff and other fans. Where the team starts and finishes is a complex point that requires attention. Regardless of the collective noun applied, however, we support - like Swanson and Kent provide - a reasoned argument as to why one is used over another. Given the theoretical nuances we have discussed, there seems little justification for the continued use of fan or spectator identification to problems focussed on the connotations of group membership.

Team identification research appears best suited to problems that are concerned with the homogenising influences of group membership on consumer behaviour. These groups can range in size and complexity, as shown in recent work (Lock \& Funk, 2016). We retain a relatively poor understanding of how sport marketers can activate group identities so that they become a salient frame of reference guiding behaviour for consumers across a broader range of situations. Moreover, we know little about how sport organisations can furnish team (organisational) identities with values, symbols and totems that render the group salient and enhance its normative content to simplify fans consumption decisions. These are significant research problems that have theoretical relevance to sport management and marketing scholars broadly. 


\section{Defining 'team' identification}

Having distinguished between fan and team identification, there is a need to offer theoretically-driven concept definitions. Rather than offering new definitions, we recommend existing and taken-for-granted ones from social psychology to provide theoretical continuity with the roots of each approach.

Fan (spectator) identification. A working definition of fan identification (identity) needs to place a sport consumer in a social structure conducive to role performance. Current applications of identity theory in sport consumer research tend to use Trail et al.'s (2000) broad definition that includes objects, people and groups. Due to its breadth, the definition lacks some specificity in relation to identity theory. For this reason, we endorse Burke and Stets (1999, p. 349) definition in which 'an identity is a set of meanings applied to the self in a social role (e.g., sport fan) or situation (e.g., supporting a team), defining what it means to be who one is in that role or situation'. This places the performance of roles in a social context, which broadly aligns with the propositions we have discussed. It is crucial to state, however, that fan identification operates and competes with other role identities in a person's salience hierarchy. Thus, based on the propositions discussed here, there is a need to consider the relative salience of a fan (spectator) identity by measuring multiple role identities beyond the narrow focus on team, player, community that persists in prior research.

Team identification. In studies drawing on social identity research, we see little reason to deviate from Tajfel's (1982, p. 255) original statement of social identity (identification) as 'that part of the individuals' self-concept which derives from their knowledge of their membership of a social group/s [sport team] together with the value and emotional significance of that membership'. We have not modified this definition to focus solely on sport teams in light of recent evidence that illustrates the pervasive role of subgroups (Bernache-Assollant, Bouchet, Auvergne, \& Lacassagne, 2011; Katz \& Heere, 
2013; Lock \& Funk, 2016) and external communities in consumer action (Heere et al., 2011; Heere \& James, 2007a). Tajfel's definition applies well to small groups, large groups, and external communities.

\section{Measuring team and fan identification}

The majority of the literature published on fan (role) and team (group) identification includes quantitative measurements of the construct. Therefore, in light of the theoretical inconsistencies we have covered, some discussion of measurement seems important. In sport management, there are three one-dimensional instruments applied to measure team identification: the Sport Spectator Identity Scale (SSIS) (Wann \& Branscombe, 1993), TII (Trail et al., 2003), and Mael and Ashforth's (1992) organisational identity scale. There are also two multi-dimensional instruments that were designed to address issues with the theoretical and content validity of the SSIS and TII: The Team*ID scale (Heere and James, 2007b), and Dimmock et al.'s (2005) team identification scale. Although these multidimensional scales were developed with a stronger theoretical basis, the SSIS and TII are still favoured by many researchers due to brevity and practical utility. In this section, we articulate four points for consideration in relation to existing measurement instruments.

First, the SSIS and TII were both developed without a clear theoretical basis. As the theoretical basis underpinning the generation of items was weak, it is difficult to assess what the items (and scale) were designed to measure. For instance, some TII items seem to focus on the fan role. Discussing the creation of the TII recently, Trail et al. (in press, p. 4) explain that the scale developed from social identity theory before asserting that it provides a more accurate measure of role identity (e.g., I consider myself to be a "real" fan of the team). Rather than emerging from a deductive process grounded in theory, however, Trail et al. imply that the TII's alignment with role identification emerged somewhat by accident. 
Although sometimes implicit, the work underpinning the SSIS emerges from a group based standpoint, which includes the work of social identity theorists (e.g., Branscombe, Wann, Noel, \& Coleman, 1993). Yet, the items in the SSIS do not exclusively measure group-based aspects of identity. For example, one item asks consumers to rate the importance of being a fan (i.e., how important is being a fan to you?) while another displays an intergroup focus (i.e., How much do you dislike [team name] greatest rivals? (Wann \& Branscombe, 1993) seemingly blending the two theoretical approaches. Ultimately, the weak theoretical foundation of both scales offers little evidence of content validity. For the reasons articulated in this manuscript, we see the development of more theoretically driven measures that are specific to fan or team identification as a crucial progression for the field.

Second, existing literature has used fan and team identification interchangeably. Therefore, researchers have used the SSIS and TII to measure one construct. This ignores the conceptual and theoretical differences between role and group identification. To illustrate how problematic this might be, consider the following example: One of the authors has a selfimportant team identification with a European professional football team, yet has few rolebased interactions with other consumers. Thus the 'fan' role does not feature strongly in his salience hierarchy in comparison to his academic identity. In this example, role identity provides a poor measure of the author's behaviour towards the team. However, had the author been given a scale that measured identification with the team (as group) it could have explained more variance in his behaviour because he shares the common category membership with other individuals associated with the club. If we distinguish more accurately between fan and team identity it is possible to develop more valid measures to discern the effects of role and group identification.

Third, in studies using identity theory, there is an opportunity to align measurement more closely with the salience hierarchy. In a recent study, Trail et al. (in press, p. 4) 
proposed that measurement should capture the notion that a 'role identity... represents how important being a fan of a particular team is to that individual'. However, this definition divorces the symbolic interactionist propositions advanced by identity theorists from the reasons for consumer behaviour. While a consumer might indicate that being a team fan is extremely important on a Likert-scale, when presented with other roles as points for comparison his fan identity might pale into insignificance in relation to his role as a father or lawyer. This speaks to a limitation of previous work that measures identification only with the fan role (e.g., Arnett et al., 2003; Dwyer et al., 2013; Laverie \& Arnett, 2000; Trail et al., 2005). By concentrating on measurement of a single role (or multiple roles to do with one team), scholars omit the theoretical importance of the interplay between social roles in an individual's salience hierarchy.

Fourth, the TII includes one item that aligns closely with the definition of social commitment (i.e. I would experience a loss if I had to stop being a fan of the team) (Stryker \& Serpe, 1994). However, theorising about the relationship between social commitment and role salience is broadly absent. Outside of research on sport consumers, scholars have developed nuanced ways of measuring social commitment (e.g., Curry \& Weaner, 1987), but these instruments have not permeated instruments or research designs in sport. There is a clear opportunity, therefore, for future research to develop measures of the quantitative and qualitative components of social commitment in order to test how ties to roles enhance, for example, team loyalty and behaviour. This would provide a useful perspective through which to advance recent findings on the relative influence of consumer relationships and team identification (Yoshida et al., 2015).

\section{Conclusion}

Our purpose in this paper was to present a theoretical analysis to make some sense of the differing effect of role and group identification on sport consumer behaviour. To this end, 
we have critically analysed the manner in which scholars have defined, conceptualised, and theoretically framed team identification research. This revealed that the authors of existing research use a plurality of terms, concepts, and foci. We do not distance ourselves from this criticism, as we have both conducted research that has added to, or avoided discussing, the issues we have set out during this manuscript.

The differences between identity theory and the social identity approach are not arbitrary. Each approach concentrates on different levels of analysis and provides varying explanations for consumer behaviour. Combined, however, they provide a much broader understanding of how identity processes shape consumer action. Our endeavour has been to provide a clear framework so that future applications of identity theory and the social identity approach can more accurately match theory to problem. This provides a pathway to consider the influence of salience hierarchies, social commitment, and role-counter-role interactions as relational variables that shape how consumers orientate themselves during the process of cocreating value with organisations. Where shared identity between members of groups attracts research attention, we would encourage researchers to use the social identity approach due to its explicit focus on this level of analysis. It offers the opportunity to explore how marketers can render group identities salient and imbue what consumers share with normative content that informs decision-making.

To conclude, we have focussed this manuscript on making sense of the existing theoretical approaches used to understand team identification. It does not provide a review of all theoretical approaches to consumer identities or behaviours. We fully acknowledge this point and see great value in authors utilising other approaches to advance our understanding of sport consumers. In instances that researchers introduce new approaches to broaden the theoretical horizons covered here, we hope that the confusion discussed in this paper underlines the need to critically engage with how new perspectives extend and differ from 
existing ones. If this ensues, we can benefit from the diversity of the sport management academy without falling foul of the weaknesses that a lack of critical engagement can create. In turn, this can address our identity crisis and provide a clear and flexible basis from which we can advance knowledge of sport consumer behaviour in the future.

\title{
Endnote
}

\begin{abstract}
${ }^{1}$ In this paper, we use the term team identification, consistently, until the end of the theoretical framework. We acknowledge that Wann and Branscombe (1993), and others, use the terms fan/team/spectator/organisation identification as the noun prior to 'identification' with a sport team. In doing so, we acknowledge Swanson and Kent's (2015) argument that (a) fan identification is an antiquated term, and (b) a team identity is nested within a broader organisational structure. Our decision to use team identification consistently is due to a need for simplicity and clarity. In the implications section of this manuscript, we seek to extend Swanson and Kent's (2015) argument on the nouns that pre-empt identification (e.g., fan/spectator and team/organisation) based on our review of identity theory and the social identity approach.

${ }^{2}$ Identity theorists tend to describe their theoretical position as sociological social psychology (cf. Stryker, 2008). We reference sociology here as the symbolic interactionist approach that underpins identity theory draws unabashedly from this discipline (Hogg, Terry, \& White, 1995; Stets \& Burke, 2000; Stryker, 2008).

${ }^{3}$ Trail et al. (2000, pp. 165-166) provide the broadest definition of team identification, to date. It includes a person's orientation of self in relation to objects, people, or groups and, as such, provides a more expansive perspective on sport consumer identity processes than role or group identity.
\end{abstract}




\section{References}

Abrams, D., \& Hogg, M. (1988). Comments on the motivational status of self-esteem in social identity and intergroup discrimination. European Journal of Social Psychology, $18,317-334$.

Abrams, D., \& Hogg, M. (2004). Metatheory: Lessons from social identity research. Personality and Social Psychology Review, 8, 98-106.

Andrijiw, A., \& Hyatt, C. (2009). Using optimal distinctiveness theory to understand identification with a nonlocal professional hockey team. Journal of Sport Management, 23, 156-181.

Arnett, D., German, S., \& Hunt, S. (2003). The identity salience model of relationship marketing success: The case of nonprofit marketing. Journal of Marketing, 67, 89105.

Ashforth, B., \& Mael, F. (1989). Social identity theory and the organization. Academy of Management Review, 14, 20-39.

Ashmore, R., Deaux, K., \& McLaughlin-Volpe, T. (2004). An organizing framework for collective identity: Articulation and significance of multidimensionality. Psychological Bulletin, 130, 80-114.

Bernache-Assollant, I., Bouchet, P., Auvergne, S., \& Lacassagne, M. (2011). Identity crossbreeding in soccer fan groups: A social approach. The case of Marseille (France). Journal of Sport \& Social Issues, 35, 72-100.

Bernache-Assollant, I., Chantal, Y., Bouchet, P., \& Lacassagne, M. (2016). Understanding the consequences of victory amongst sport spectators: The mediating role of BIRGing. European Journal of Sport Science, 16, 716-725. 
Bernache-Assollant, I., Laurin, R., \& Bodet, G. (2012). Casual spectators and die-hard fans' reactions to their team defeat: A look at the role of territorial identification in elite French rugby. International Journal of Psychological Research, 5, 122-132.

Bodet, G., \& Bernache-Assollant, I. (2011). Consumer loyalty in sport spectatorship services: The relationships with consumer satisfaction and team identification. Psychology and Marketing, 28, 781-802.

Boyle, B., \& Magnusson, P. (2007). Social identity and brand equity formation: A comparative study of collegiate sports fans. Journal of Sport Management, 21, 497520.

Branscombe, N., \& Wann, D. (1992). Role of identification with a group, arousal, categorization processes, and self-esteem in sports spectator aggression. Human Relations, 45, 1013-1033.

Branscombe, N., Wann, D., Noel, J., \& Coleman, J. (1993). In-group or out-group extremity: Importance of the threatened social identity. Personality and Social Psychology Bulletin, 19, 381-388.

Brewer, M. (1991). The social self: On being the same and different at the same time. Personality and Social Psychology Bulletin, 17, 475-482.

Brewer, M. (2001). The many faces of social identity: Implications for political psychology. Political Psychology, 22, 115-125.

Burke, P., \& Reitzes, D. (1981). The link between identity and role performance. Social Psychology Quarterly, 44, 83-92.

Burke, P., \& Stets, J. (1999). Trust and commitment through self-verification. Social Psychology Quarterly, 62, 347-366.

Callero, P. (1985). Role-identity salience. Social Psychology Quarterly, 48, 203-215. 
Curry, T., \& Weaner, J. (1987). Sport identity salience, commitment, and the involvement of self in role: Measurement issues. Sociology of Sport Journal, 4, 280-288.

Deaux, K., \& Martin, D. (2003). Interpersonal networks and social categories: Specifying levels of context in identity processes. Social Psychology Quarterly, 66, 101-117.

Delia, E. (2015). The exclusiveness of group identity in celebrations of team success. Sport Management Review, 18, 396-406.

Dimmock, J. (2009). The influence of assimilation and differentiation needs on sport team preferences: The quest for optimal distinctiveness. International Journal of Sport Psychology, 40, 392-402.

Dimmock, J., Grove, J., \& Eklund, R. (2005). Reconceptualising team identification: New dimensions and their relationship to intergroup bias. Group Dynamics: Theory, Research and Practice, 9, 75-86.

Doyle, J., Lock, D., Filo, K., Funk, D., \& McDonald, H. (in press). “I was there from the start": The identity maintenance strategies used by fans to combat the threat of losing. Sport Management Review.

Dwyer, B., Drayer, J., \& Shapiro, S. (2013). Proceed to checkout? The impact of time in advanced ticket purchase decisions. Sport Marketing Quarterly, 22, 166-180.

Eagly, A., \& Chaiken, S. (1993). The psychology of attitudes. Fort Worth: Harcourt Brace.

Elsbach, K. (1999). An expanded model of organizational identification. Research in Organizational Behavior, 21, 163-200.

Fink, J., Parker, H., Brett, M., \& Higgins, J. (2009). Off-field behavior of athletes and team identification: Using social identity theory and balance theory to explain fan reactions. Journal of Sport Management, 23, 142-155.

Fink, J., Trail, G., \& Anderson, D. (2002). An examination of team identification: Which motives are most salient to its existence? International Sports Journal, 6, 195-207. 
Fisher, R., \& Wakefield, K. (1998). Factors leading to group identification: A field study of winners and losers. Psychology and Marketing, 15, 23-40.

Forehand, M., Deshpandé, R., \& Reed, A. (2002). Identity salience and the influence of differential activation of the social self-schema on advertising response. Journal of Applied Psychology, 87, 1086-1099.

Foster, W., \& Hyatt, C. (2007). I despise them! I detest them! Franchise relocation and the expanded model of organizational identification. Journal of Sport Management, 21, $194-212$.

Foster, W., \& Hyatt, C. (2008). Inventing team tradition: A conceptual model for the strategic development of fan nations. European Sport Management Quarterly, 8, 265-287.

Funk, D., \& James, J. (2001). The psychological continuum model: a conceptual framework for understanding an individual's psychological connection to sport. Sport Management Review, 4, 119-150.

Gantz, W. (1981). An exploration of viewing motives and behaviors associated with television sports. Journal of Broadcasting \& Electronic Media, 25, 263-275.

Goldman, M., Chadwick, S., Funk, D., \& Wocke, A. (2016). I am distinctive when I belong: meeting the need for optimal distinctiveness through team identification. International Journal of Sport Management and Marketing, 16, 198-220.

Gwinner, K., \& Swanson, S. (2003). A model of fan identification: Antecedents and sponsorship outcomes. Journal of Services Marketing, 17, 275-294.

Heere, B. (2016). Team identity theory. In G. Cunningham, J. Fink, \& A. Doherty (Eds.), Routledge handbook of theory in sport management (pp. 213-222). New York: Taylor \& Francis. 
Heere, B., \& James, J. (2007a). Sports teams and their communities: Examining the influence of external group identities on team identity. Journal of Sport Management, 21, 319337.

Heere, B., \& James, J. (2007b). Stepping outside the lines: Developing a multi-dimensional team identity scale based on social identity theory. Sport Management Review, 10, $65-91$.

Heere, B., Walker, M., Yoshida, M., Ko, Y., Jordan, J., \& James, J. (2011). Brand community development through associated communities: Grounding community measurement within social identity theory. The Journal of Marketing Theory and Practice, 19, 407-422.

Hogg, M., \& Smith, J. (2007). Attitudes in social context: A social identity perspective. European Review of Social Psychology, 18, 89-131.

Hogg, M., Terry, D., \& White, K. (1995). A tale of two theories: A critical comparison of identity theory with social identity theory. Social Psychology Quarterly, 58, 255-269.

Holt, D. (1995). How consumers consume: A typology of consumption practices. Journal of Consumer Research, 22, 1-16.

Hornsey, M., \& Jetten, J. (2004). The individual within the group: Balancing the need to belong with the need to be different. Personality and Social Psychology Review, 8, $248-264$.

Jacobson, B. (2003). The social psychology of the creation of a sports fan identity: A theoretical review of the literature. Athletic Insight: The Online Journal of Sports Psychology, 5. Retrieved from www.athleticinsight.com.

Katz, M., \& Heere, B. (2013). Leaders and followers: An exploration of the notion of scalefree networks within a new brand community. Journal of Sport Management, 27, 271-287. 
Katz, M., \& Heere, B. (2015). Empowerment within brand communities: Overcoming the Achilles' Heel of scale-free networks. Sport Management Review, 18, 370-383.

Katz, M., \& Heere, B. (2016). New team, new fans: A longitudinal examination of team identification as a driver of university identification. Journal of Sport Management, $30,135-148$.

Kleine, R., \& Kleine, S. (2000). Consumption and self-schema changes throughout the identity project life cycle. Advances in Consumer Research, 27, 279-285.

Kwon, H., Trail, G., \& Anderson, D. (2005). Are multiple points of attachment necessary to predict cognitive, affect, conative, or behavioral loyalty? Sport Management Review, $8,255-270$.

Lalonde, R. (1992). The dynamics of group differentiation in the face of defeat. Personality and Social Psychology Bulletin, 18, 336-342.

Laverie, D., \& Arnett, D. (2000). Factors affecting fan attendance: The influence of identity salience and satisfaction. Journal of Leisure Research, 32, 225-246.

Lock, D., \& Funk, D. (2016). The multiple in-group identity framework. Sport Management Review, 19, 85-96.

Lock, D., Funk, D., Doyle, J., \& McDonald, H. (2014). Examining the structural composition and longitudinal change of team identification. Journal of Sport Management, 28, $119-135$.

Lock, D., Taylor, T., \& Darcy, S. (2011). In the absence of achievement: The formation of new team identification. European Sport Management Quarterly, 11, 171-192.

Lock, D., Taylor, T., Funk, D., \& Darcy, S. (2012). Exploring the development of team identification. Journal of Sport Management, 26, 283-294.

Luellen, T., \& Wann, D. (2010). Rival salience and sport team identification. Sport Marketing Quarterly, 19, 97-106. 
Madrigal, R. (2000). The influence of social alliances with sports teams on intentions to purchase corporate sponsors' products. Journal of Advertising, 29, 13-24.

Mael, F., \& Ashforth, B. (1992). Alumni and their alma mater: A partial test of the reformulated model of organizational identification. Journal of Organizational Behavior, 13, 103-123.

Mahony, D. (1995). The effect of the personality variable of self - monitoring on individual loyalty to professional football teams. Ohio State University, Columbus.

Mahony, D., Madrigal, R., \& Howard, D. (2000). Using the psychological commitment to team (PCT) scale to segment sport consumers based on loyalty. Sport Marketing Quarterly, 9, 15-25.

McCall, G., \& Simmons, J. (1978). Identities and interactions. New York: Free Press.

Mead, G. (1934). Mind, self, and society. Chicago: University of Chicago Press.

Oakes, P., Turner, J., \& Haslam, S. (1991). Perceiving people as group members: The role of fit in the salience of social categorizations. British Journal of Social Psychology, 30, $125-144$.

Prentice, D., Miller, D., \& Lightdale, J. (1994). Asymmetries in attachments to groups and to their members: Distinguishing between common-identity and common-bond groups. Personality and Social Psychology Bulletin, 20, 484-493.

Pritchard, M., Stinson, J., \& Patton, E. (2010). Affinity and affiliation: The dual-carriage way to team identification. Sport Marketing Quarterly, 19, 67-77.

Reed, A. (2002). Social identity as a useful perspective for self-concept-based consumer research. Psychology \& Marketing, 19, 235-266.

Reed, A. (2004). Activating the self-importance of consumer selves: Exploring identity salience effects on judgments. Journal of Consumer Research, 31, 286-295. 
Rees, T., Haslam, A., Coffee, P., \& Lavallee, D. (2015). A social identity approach to sport psychology: Principles, practice, and prospects. Sports Medicine, 45, 1083-1096.

Reysen, S., Snider, J., \& Branscombe, N. (2012). Corporate renaming of stadiums, team identification, and threat to distinctiveness. Journal of Sport Management, 26, 350357.

Robinson, M., \& Trail, G. (2005). Relationships among spectator gender, motives, points of attachment, and sport preference. Journal of Sport Management, 19, 58-80.

Serpe, R. T. (1987). Stability and change in self: A structural symbolic interactionist explanation. Social Psychology Quarterly, 50, 44-55.

Shapiro, S., Ridinger, L., \& Trail, G. (2013). An analysis of multiple spectator consumption behaviors, identification, and future behavioral intentions within the context of a new college football program. Journal of Sport Management, 27, 130-145.

Sluss, D., \& Ashforth, B. (2008). How relational and organizational identification converge: Processes and conditions. Organization Science, 19, 807-823.

Smith, A., Graetz, B., \& Westerbeek, H. (2008). Sport sponsorship, team support and purchase intentions. Journal of Marketing Communications, 14, 387-404.

Stets, J., \& Burke, P. (2000). Identity theory and social identity theory. Social Psychology Quarterly, 63, 224-237.

Stets, J., \& Burke, P. (2003). A sociological approach to self and identity. In M. Leary \& J. Tangney (Eds.), Handbook of self and identity (pp. 128-152). New York: The Guilford Press.

Stets, J., \& Burke, P. (2014). The development of identity theory. Advances in Group Processes, 31, 57-97.

Stryker, S. (1968). Identity salience and role performance: The relevance of symbolic interaction theory for family research. Journal of Marriage and Family, 30, 558-564. 
Stryker, S. (2008). From Mead to a structural symbolic interactionism and beyond. Annual Review of Sociology, 34, 15-31.

Stryker, S., \& Serpe, R. (1982). Commitment, identity salience, and role behavior: Theory and research example. In W. Icke \& E. Knowles (Eds.), Personality, roles, and social behavior (pp. 199-218). New York: Springer.

Stryker, S., \& Serpe, R. (1994). Identity salience and psychological centrality: Equivalent, overlapping, or complementary concepts? Social Psychology Quarterly, 57, 16-35.

Sutton, W., McDonald, M., Milne, G., \& Cimperman, J. (1997). Creating and fostering fan identification in professional sports. Sport Marketing Quarterly, 6, 15-22.

Swanson, S., \& Kent, A. (2015). Fandom in the workplace: Multi-target identification in professional team sports. Journal of Sport Management, 29, 461-477.

Tajfel, H. (1969). Cognitive aspects of prejudice. Journal of Social Issues, 25, 79-97.

Tajfel, H. (1982). Social psychology of intergroup relations. Annual Review of Psychology, $33,1-39$.

Tajfel, H., \& Turner, J. (1979). An integrative theory of intergroup conflict. In W. Austin \& S. Worchel (Eds.), The Social Psychology of Intergroup Relations (pp. 33-47). Monterey: Brooks/Cole Publishing Company.

Theodorakis, N., Dimmock, J., Wann, D., \& Barlas, A. (2010). Psychometric evaluation of the team identification scale among Greek sport fans: A cross-validation approach. European Sport Management Quarterly, 10, 289-305.

Theodorakis, N., Wann, D., \& Weaver, S. (2012). An antecedent model of team identification in the context of professional soccer. Sport Marketing Quarterly, 21, 80-90.

Thoits, P., \& Virshup, L. (1997). Me's and we's: forms and functions of social identities. In R. Ashmore \& L. Jussim (Eds.), Self and Identity : Fundamental Issues: Fundamental Issues (pp. 106-133). New York: Oxford University Press. 
Trail, G., Anderson, D., \& Fink, J. (2000). A theoretical model of sport spectator consumption behavior. International Journal of Sport Management, 1(3), 154-180.

Trail, G., Anderson, D., \& Fink, J. (2005). Consumer satisfaction and identity theory: A model of sport spectator conative loyalty. Sport Marketing Quarterly, 14, 98-111.

Trail, G., Anderson, D., \& Lee, D. (in press). A longitudinal study of team-fan role identity on self-reported attendance behavior and future intentions. Journal of Amateur Sport, $1-14$.

Trail, G., \& James, J. (2016). Seven deadly sins of manuscript writing: Reflections of two experienced reviewers. Journal of Global Sport Management, 1, 142-156.

Trail, G., Robinson, M., Dick, R., \& Gillentine, A. (2003). Motives and points of attachment: Fans versus spectators in intercollegiate athletics. Sport Marketing Quarterly, 12, $217-227$.

Turner, J. (1982). Towards a cognitive redefinition of the social group. In H. Tajfel (Ed.), Social identity and intergroup relations. Cambridge: Cambridge University Press.

Turner, J., \& Brown, R. (1978). Social status, cognitive alternatives and intergroup relations. In H. Tajfel (Ed.), Differentiation between social groups: Studies in the social psychology of intergroup relations (pp. 201-234). London: Academic Press.

Turner, J., Hogg, M., Oakes, P., Reicher, S., \& Wetherell, M. (1987). Rediscovering the social group: A self-categorization theory. London: Blackwell.

Turner, J., Oakes, P., Haslam, S., \& McGarty, C. (1994). Self and collective: Cognition and social context. Personality and Social Psychology Bulletin, 20, 454-463.

Uhrich, S. (2014). Exploring customer-to-customer value co-creation platforms and practices in team sports. European Sport Management Quarterly, 14, 25-49. 
Underwood, R., Bond, E., \& Baer, R. (2001). Building service brands via social identity: Lessons from the sports marketplace. Journal of Marketing Theory and Practice, 9, $1-13$.

Wann, D., \& Branscombe, N. (1990). Die-hard and fair-weather fans: Effects of identification on BIRGing and CORFing tendencies. Journal of Sport and Social Issues, 14, $103-$ 117.

Wann, D., \& Branscombe, N. (1993). Sports fans: Measuring degree of identification with their team. International Journal of Sports Psychology, 24, 1-17.

Wann, D., Fahl, C., Erdmann, J., \& Littleton, J. (1999). Relationship between identification with the role of sport fan and trait aggression. Perceptual and Motor Skills, 88, 12961298.

Wann, D., Melnick, M., Russell, G., \& Pease, D. (2001). Sport fans: the psychology and social impact of spectators. New York: Routledge.

Wann, D., \& Schrader, M. (1996). An analysis of the stability of sport team identification. Perceptual and Motor Skills, 82, 322-322.

Wann, D., Tucker, K., \& Schrader, M. (1996). An exploratory examination of the factors influencing the origination, continuation and cessation of identification with sports teams. Perceptual and Motor Skills, 82, 995-1001.

Wann, D., Waddill, P., Polk, J., \& Weaver, S. (2011). The team identification-social psychological health model: Sport fans gaining connections to others via sport team identification. Group Dynamics: Theory, Research, and Practice, 15, 75-89.

Worchel, S., Iuzzini, J., Coutant, D., \& Ivaldi, I. (2000). A multidimensional model of identity: Relating individual and group identities to intergroup behaviour. In D. Capozza \& R. Brown (Eds.), Social identity processes (pp. 15-32). London: Sage. 
Yoshida, M., Heere, B., \& Gordon, B. (2015). Predicting behavioral loyalty through community: Why other fans are more important than our own intentions, our satisfaction, and the team itself. Journal of Sport Management, 29, 318-333. 


\begin{tabular}{|l|}
\hline "The extent to which individuals perceive \\
themselves as fans of the team, are involved with \\
the team, are concerned with the team's \\
performance, and view the team as a \\
representation of themselves" (Branscombe \& \\
Wann, 1992, p. 1017) \\
\hline
\end{tabular}

Wann, 1992, p. 1017)
"That part of the individuals' self-concept

which derives from their knowledge of their membership of a social group/s [sport team]

together with the value and emotional

significance of that membership" (Tajfel, 1981, p. 255 cited by Underwood, Bond \& Bauer,

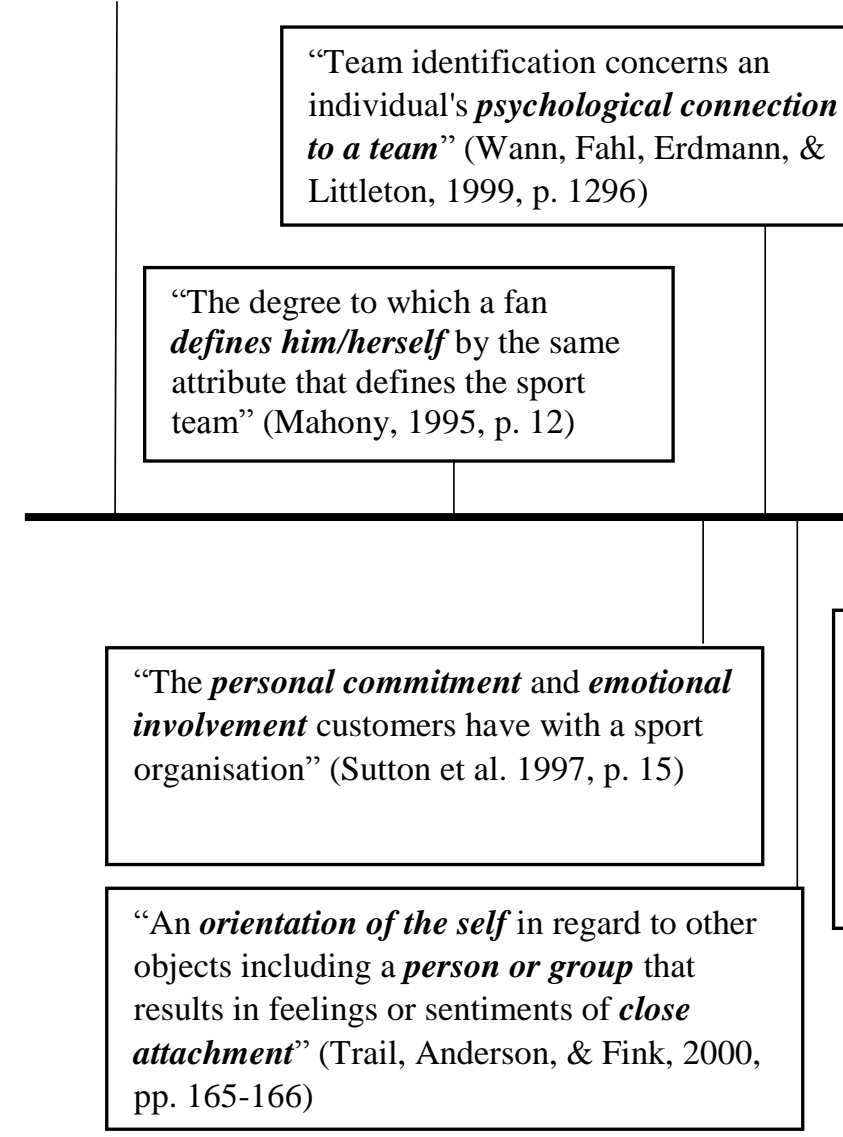

"Team identification is defined as the spectators perceived connectedness to a team and the experience of the team's

failings and achievements as one's own" (Gwinner \& Swanson, 2003, p. 276)

defines the sport
"A self-perception based on (1) a sense of active connection between one's identity and the identity of an organisation, and (2) a positive

relational categorization of oneself and the organisation" (Elsbach, 1999, cited in Foster \& Hyatt, 2007, p. 198)

Figure 1: Team/organisational identification definition timeline

"A fan's psychological connection to a team and the extent to which the fan views the team as an extension of his or herself"

(Wann, 2011,p. 76)

"Spectators' perceived connectedness to a team and its performance" (Smith, Graetz, \& Westerbeek, 2008, p. 389)
"The perception of oneness with or

belongingness to some human aggregate"

(Ashforth \& Mael, 1989, cited in Fink,

Parker, Brett, \& Higgins, 2009, p. 143)

"Team identity [identification] is that part of an individual's self-concept, which derives from membership in a

community anchored around a sports team, based on the emotional value attached to that membership, and the knowledge of, engagement with, and evaluation of the community itself" (Heere, 2016, p. 216) 
Table 1: Comparison of identity theory and social identity approach conceptualisation

\begin{tabular}{|c|c|c|}
\hline Concept & Identity theory & Social identity approach \\
\hline Focus & $\begin{array}{l}\text { Social roles (e.g., sport fan, mother, } \\
\text { sister, runner) }\end{array}$ & $\begin{array}{l}\text { Social groups (e.g., teams, } \\
\text { universities, nations) }\end{array}$ \\
\hline Formation & $\begin{array}{l}\text { Patterns of social structure increase } \\
\text { or decrease the likelihood that a } \\
\text { consumer will inhabit specific } \\
\text { social roles. }\end{array}$ & $\begin{array}{l}\text { Consumers seek out group } \\
\text { memberships that are coherent with, } \\
\text { or an extension of, their self-concept. }\end{array}$ \\
\hline Cognition & $\begin{array}{l}\text { A self-cognition of role occupation } \\
\text { that (re)produces ties between a } \\
\text { consumer and other individuals } \\
\text { within a social structure (e.g., sport } \\
\text { team). }\end{array}$ & $\begin{array}{l}\text { A cognitive realisation of } \\
\text { membership in a team identity that is } \\
\text { evaluated in relation to out-groups. }\end{array}$ \\
\hline 'Salience' & $\begin{array}{l}\text { The placement of a role in a } \\
\text { consumer's salience hierarchy } \\
\text { influences its primacy in decision } \\
\text { making. Roles that tie a consumer } \\
\text { to a greater number of people in a } \\
\text { meaningful way (i.e., social } \\
\text { commitment) occupy more } \\
\text { prominent positions in her salience } \\
\text { hierarchy. }\end{array}$ & $\begin{array}{l}\text { The extent that a team identity is an } \\
\text { active part of a consumer's self- } \\
\text { concept and provides a guide for } \\
\text { decision-making. A team identity } \\
\text { becomes salient in situations } \\
\text { rendered relevant by stimulus cues, } \\
\text { the social environment, or the self- } \\
\text { importance of team identification to } \\
\text { a consumer. }\end{array}$ \\
\hline $\begin{array}{l}\text { Behavioural } \\
\text { reference } \\
\text { frame }\end{array}$ & $\begin{array}{l}\text { Role occupation provides a } \\
\text { framework for behaviour as a result } \\
\text { of symbolic interactions with other } \\
\text { consumers that perform counter- } \\
\text { roles. The role - counter-role } \\
\text { dynamics in specific social } \\
\text { structures are verified personally, } \\
\text { by a consumer and socially, by the } \\
\text { other actors in a context. Role } \\
\text { verification leads to self-esteem. }\end{array}$ & $\begin{array}{l}\text { Shared team identity exposes } \\
\text { consumers to modes of normative } \\
\text { behaviour that reflect common } \\
\text { understandings of the group. When } \\
\text { salient, the team identity provides a } \\
\text { basis for behaviour that is ritualistic, } \\
\text { in-group favouring, and, where } \\
\text { appropriate, designed to enhance } \\
\text { group status in relation rivals. }\end{array}$ \\
\hline
\end{tabular}

